\title{
Impact of assertive and defensive impression management tactics on recruiter evaluation: The case of post-failure entrepreneurs in employment Interviews
}

\section{Julien Cusin*}

IRGO, IAE Bordeaux, University of Bordeaux

\section{Juliette Passebois-Ducros}

IRGO, IAE Bordeaux, University of Bordeaux

\section{Abstract}

This study investigates how human-resource professionals examine, during a job interview, the application of post-bankruptcy entrepreneurs seeking to rebound as salaried workers. We assume that the way candidates talk about their failure (impression management tactics-IM) impacts the assessment of the recruiter. Thanks to an experimental methodology we compare the impact of three distinct IM tactics on the assessment of the hiring manager (a defensive IM tactic based on excuses, a defensive IM tactic based on justification, and an assertive IM tactic). We demonstrate that recruiters are more inclined to recruit the post-bankruptcy entrepreneur if the candidate has been able to turn the ordeal into an element of selfvalorization.

Keywords: impression management, failure, entrepreneur, recruitment, employment interview

\section{Résumé}

Cet article s'intéresse à l'évaluation par les professionnels des ressources humaines d'un cas particulier de candidat à l'emploi : les entrepreneurs ayant subi un échec. Nous montrons que la manière de raconter son échec durant un entretien de recrutement, à travers des stratégies de management de l'impression, peuvent affecter l'évaluation faite par le recruteur. Nous exposons les résultats d'une expérimentation s'appuyant sur trois scénarios de gestion de

\footnotetext{
* Please address correspondence to: Julien Cusin, IAE Bordeaux, Pôle Universitaire de Sciences de Gestion, 35 Avenue Abadie, 33072 Bordeaux Cedex, France. Email: julien.cusin@u-bordeaux.fr
} 
l'impression : une stratégie défensive fondée sur l'excuse, une stratégie défensive fondée sur la justification, et une stratégie assertive. Nous montrons que les professionnels des ressources humaines sont plus enclins à recruter l'entrepreneur post-faillite s'il fait de son échec un élément de valorisation.

Mots clés : gestion de l'impression, échec, entrepreneuriat, recrutement, entretien d'embauche

\section{Introduction}

There is a considerable body of literature on the impression management (IM) tactics used by applicants during job interviews to influence the way they are perceived. These studies focus particularly on the efficiency of IM tactics in terms of personnel selection (Chen, Yang, \& Lin, 2010; Chen \& Lin, 2014). On this issue, assertive (that is, attempts to actively construct a favourable image) and defensive (that is, attempts to repair a tarnished image) IM tactics are traditionally distinguished. However, until now, the vast majority of these works have focused on assertive behaviours, which appear to be of higher value for candidates who are attempting to increase their likelihood of getting hired (Chen \& Lin, 2014; Tsai, Huang, Wu, \& Lo, 2010).

And yet, outside the context of job interviews, only defensive behaviours - mainly through external attribution-are discussed in the literature when individuals have to report past failures (Zacharakis, Meyer, \& DeCas, 1999). This is understandable, because a person who has undergone a professional failure expects to be judged harshly, and even stigmatized (Savitsky, Epley, \& Gilovich, 2001; Shepherd \& Patzelt, 2015). Since the types of questions asked by recruiters are assumed to condition the kind of IM tactics adopted by applicants (Ellis, West, Ryan, \& DeShon, 2002), it is not surprising that questions on past unfavourable performance lead to defensive behaviours (apologies, justifications, or excuses) during a job interview. As such, defensive IM tactics can help applicants mitigate unfavourable evaluations arising from interviewers' negative concerns (Tsai et al., 2010). Nevertheless, the literature 
strongly emphasizes the positive virtues of failure in terms of learning (Cope, 2011; Ucbasaran, Shepherd, Lockett, \& Lyon, 2013). Therefore, one might consider a more assertive behaviour among applicants during the job interview, explaining how past failure allowed them to acquire new knowledge, grow professionally, develop specific characteristics, or overcome obstacles.

The idea that individuals who have suffered failure in the past are likely to use IM tactics has very occasionally been defended in the literature (Shepherd \& Haynie, 2011). However, we find that the post-failure behaviour of people during the specific context of a job interview has rarely been discussed. Certainly, Jackson, Hall, Rowe, and Daniels (2009) studied post-failure attributions during job interviews, but they were not interested in the effectiveness of entrepreneurs' IM tactics, and simply focused on how individuals can be positively accompanied in their sensemaking of failure.

To our knowledge, only Silvester, Anderson-Gough, Anderson, and Mohamed (2002) focus on how individuals can elicit a favourable impression according to whether they attribute failure to internal or external causes. However, in this study, the authors call for an extension of their research work focusing on the role of discourse strategies during a job interview. Furthermore, Silvester et al. (2002) study the very particular case of students who failed an exam, a failure that is not particularly stigmatizing vis-à-vis a recruiter when compared with, for example, a bankruptcy. We were surprised that so little of the literature addresses the salient case of post-bankruptcy entrepreneurs (PBEs) seeking to rebound as salaried workers. Of course, the difficulty PBEs have finding new employment has already been noted (Ucbasaran et al., 2013), but the corresponding remarks are very allusive and have never been subject to a comprehensive study. This is all the more troubling given that there are many bankruptcies (Ucbasaran et al., 2013) and that most PBEs struggle to restart a business (Simmons, Wiklund, \& Levie, 2014).

By necessity, many of these entrepreneurs find themselves in a situation of job interviews. Very quickly, they thus have to decide on how to tell their failure stories so as to 
elicit the best impression. There is therefore a clear need for research that broadens our understanding of IM tactics used by this specific type of applicant. Should PBEs protect their image (through excuses or justification), assuming that failure is a black spot on their application (defensive tactic)? Or should they on the contrary consider that failure is a rewarding event they can use in their discourse to build a favourable image (assertive tactic)? In this research, we compare the respective impact of defensive and assertive IM tactics in the discourse of PBEs on recruiters' evaluation in the context of job interviews.

To this end, we conducted experimental research with 169 French human-resource (HR) professionals, in the knowledge that France is a country where entrepreneurs are widely considered as the most stigmatized individuals following a professional failure (IPSOS, 2013). More specifically, we built three scenarios, each of which corresponds to different post-failure discourses of a candidate during a selection interview. One is a defensive IM tactic and is based on excuses, the second is also a defensive IM tactic but is based on justification, and the last is an assertive IM tactic. Then we performed average comparison tests. Finally, we show in this paper that recruiters attach importance to the way candidates talk about their failure during the job interview. Candidates who are not in denial, who learn from their failure, and who prove that that the experience has allowed them to progress professionally will thus be more likely to be hired.

\section{Literature Review}

\section{Impression Management Tactics During Employment Interviews}

From the plethora of literature on job interviews, there is a specific research area dedicated to impression management (IM) tactics (Van Iddekinge, McFarland, \& Raymark, 2007). IM is defined as "the conscious or unconscious attempt to control the images that are projected in [...] social interactions" (Schlenker, 1980, p. 6) and may often be used by 
candidates in evaluative contexts like employment interviews (Chen \& Lin, 2014; Roulin, Bangerter, \& Levashina, 2015). To convince the interviewer and get the job, applicants will indeed adapt their behaviour. They will especially consider what information they can share (or not) and how to frame the information provided (Rosenfeld, 1997; Tsai, Chen, \& Chiu, 2005). This does not mean that impression management is necessarily synonymous with faking. It may well be authentic and rely on true facts (Roulin et al., 2015).

According to Schneider (1981), there are four IM tactics (see Figure 1): verbal statements; nonverbal or expressive behaviours (such as smiling, eye contact, body orientation, gesturing, head movement); modifications of one's physical appearance (such as proper dress); and integrated behaviour patterns (such as favour-rendering). But verbal and nonverbal behaviours are the two main drivers (Chen et al., 2010; Van Iddekinge et al., 2007), given that "nonverbal cues affect the magnitude, but not the direction, of the impact produced by verbal behavior" (Kristof \& Stevens, 1994, p. 128). We may add here that Tedeschi and Melburg (1984) distinguish verbal IM tactics according to whether they are assertive or defensive.

On the one hand, assertive IM tactics "are used for the applicant to acquire and promote a favorable impression by portraying himself or herself as a particular type of person with particular beliefs, opinions, knowledge, characteristics, or experiences" (Ellis et al., 2002, p. 1202). Assertive IM tactics encompass two categories: self- and other-focused tactics. First, self-focused tactics (self-promotion, enhancements, overcoming obstacles, or exemplification) are designed to show that the applicant possesses desirable qualities and skills for the job (the applicant focuses the conversation on themselves). Attention can be drawn, for instance, to past accomplishments. Second, other-focused tactics (ingratiation, opinion conformity, other enhancement, feigned helplessness or fit with organization) are intended to evoke interpersonal liking and attraction between the interviewer and the applicant (the applicant focuses the conversation on the interviewer or the company) (Chen et al., 2010; Ellis et al., 2002; Tsai et al., 2005; Van Iddekinge et al., 2007). 
On the other hand, defensive IM tactics are used when applicants perceive a threat to their self-image due to their own behaviour (for instance, being late) or to information disclosed during the interview (such as having experienced a professional failure in the past). In this case, the applicant attempts to repair their tarnished image. In the literature, defensive IM tactics are frequently divided into three categories: excuses (the person denies responsibility for a negative outcome and shifts it to some external causes); justification (the person accepts responsibility in such cases, but not the negative implications, claiming that it is not as bad as it appears); and apologies (the person make amends and promises to behave appropriately in the future) (Ellis et al., 2002; Tsai et al., 2010; Van Iddekinge et al., 2007).

\section{[Insert Figure 1]}

Authors generally argue that, in the specific context of job interviews, candidates primarily use assertive impression management (Stevens \& Kristof, 1995). There is therefore a literature bias in favour of assertive tactics (Ellis et al., 2002). However, Tsai et al. (2010) note that a defensive attitude is relatively common during job interviews, especially when the recruiter questions the applicant on past unfavourable performance (such as professional failure). Moreover, this tactic appears to be effective. Indeed, "applicants may get an opportunity to clear up interviewer concerns and improve their chances of receiving an offer" (Bolino, Long, \& Turnley, 2016, p. 386). There is thus a need for more research to improve our knowledge of defensive IM tactics that have been little studied to date.

\section{Impact of IM Tactics on Recruiter Evaluation}

Several studies have shown a positive relationship between applicant IM tactics and recruiter evaluations: the applicants are more likeable, their skills are more easily perceived, and their fit with the job or organization is more obvious (Chen et al., 2010; Chen \& Lin, 2014). 
IM behaviours may even be more important than information about the applicant's objective qualifications in the decision of the recruiter (Rosenfeld, 1997). Kacmar, Delery, and Ferris (1992) find in particular that self-focused tactics are more successful than other-focused tactics.

However, the literature has established that excessive use of IM behaviours during employment interviews can be counterproductive (Rosenfeld, 1997), especially if the candidate has poor qualifications for the job, because the IM tactic will be perceived as overstatement and attempted manipulation (Gilmore \& Ferris, 1989). In other words, IM must be "skillfully executed" by the applicants (Rosenfeld, 1997, p. 803). Furthermore, some authors highlight the existence of moderating variables, like interviewers' affectivity, self-monitoring or training (Chen et al., 2010), interview structure, customer-contact requirement, or interview length (Tsai et al., 2005). For instance, applicants' IM tactics have more influence on interviewer evaluation when the extent of customer contact required for a job is high (for instance, sales representatives) (Tsai et al., 2005). It has also been demonstrated that IM tactics perform better in ambiguous situations (Kacmar \& Carlson, 1999; Rosenfeld, 1997).

\section{The Behaviour of Applicants About Their Past Failures During Job Interviews}

Among ambiguous situations that may be addressed during a job interview, some may be related to the applicants' past professional experiences. This is the case if they have experienced failure, such as bankruptcy. Shepherd and Patzelt (2015) argue that it is very difficult for an external observer-in our case, a recruiter-to know the reasons for an entrepreneurial failure. This is indeed a context of high uncertainty, regarding in particular the level of individual responsibility in this setback (Shepherd \& Patzelt, 2015; Ucbasaran et al., 2013). In practice, when the applicant makes an excuse or seeks to justify this past experience, it is not obvious for the recruiter whether the applicant's comments are the objective truth or not (Fletcher, 1992). When asked about failure, individuals may thus use IM tactics, often through causal attributions (Silvester et al., 1992). So far, this idea that causal attribution is a 
modality of IM management has been little emphasized in the literature (Shepherd \& Haynie, 2011).

The very nature of a recruiter's task is to attempt to analyze the cause of applicants' past successes and failures, in order to predict their future job performance (Struthers, Colwill, \& Perry, 1992). In this regard, attribution theory explains how individuals perceive and make judgments about past events or outcomes (Heider, 1958). More precisely, perceptions may differ in three dimensions: locus of causality (internal/dispositional vs. external/situational), stability (temporary vs. permanent) and controllability (Tucker \& Rowe, 1979). For example, applicants who have an internal locus of control (that is, who report having great control over outcomes) are inclined to use more apologies and fewer excuses to explain their past failures, and vice versa in the case of external locus of control (Tsai et al., 2010). In other words, locus of causality and controllability form a mechanism through which applicants use IM tactics. In practice, people generally exonerate themselves and attribute their failures to external factors (Huff \& Schwenk, 1990). An analysis in this vein spares the entrepreneur's ego (Zacharakis et al., 1999). In addition, during a job interview, the fear of being negatively discriminated against with respect to employment opportunities because of post-failure stigma (Shepherd \& Patzelt, 2015; Shepherd \& Haynie, 2011) could explain the entrepreneur's external attribution. If we assume there is a natural tendency to use defensive IM tactics based on excuses (that is, to deny responsibility for failure), we cannot say that these tactics are the best ones to improve the impression given to potential employers. To date, the literature has not really addressed the issue of applicants' discourses about past failure during job interviews, and their consequences on recruiter decision-making (Silvester et al., 1992). However, recent research encourages PBEs to use IM tactics that minimize the risk of social stigmatization (Kibler, Mandl, Kautonen, \& Berger, 2017). As the authors state, "we have limited knowledge of how entrepreneurs can present venture failure in a way that enhances their legitimacy with public audiences" (Kibler et al., 2017, p. 146). 
In any event, the use of different IM tactics adopted by applicants usually depends on question type (Ellis et al., 2002). Thus, as failure is a stigmatizing event, it is assumed in the literature that the applicant will have to repair their tarnished image if the failure is discussed during a job interview. "By raising their negative concerns about applicants, interviewers create in most of the applicants a feeling that they should effectively address these concerns in order to receive desired job offers. In such a circumstance, applicants may adopt defensive IM tactics in order to repair their damaged image," according to Tsai et al. (2010, p. 131). As it happens, in their study with 201 managers, "compared with the control group, applicants using defensive IM tactics received higher interviewer ratings when negative concerns surfaced" (p. 131), keeping in mind that apologies, justifications, and excuses have a similar effect on evaluation when the interviewer's preoccupation was competence related. More recently, Kibler et al. (2017) find that the most effective IM strategy for PBEs with a public audience is for the applicant to distance themselves from the failure, in particular through external attribution.

However, previous research has shown that applicants make a better impression in job interviews when they take responsibility for past failures (Jackson et al., 2009; Silvester et al., 2002). Yet it has been shown that causal attribution decreases stakeholders' confidence, as they expect entrepreneurs to be in control (Zacharakis et al., 1999). To this end, defensive strategies based on internal causality and controllability (justification or apologies) appear to be better perceived than IM tactics based on external causality (excuses). It should however be noted that the apology strategy is not very widespread in the literature and does not correspond well to the case of a PBE wishing to find employment. Indeed, this strategy involves, for example, an oral commitment of restitution to "victims" (Ellis et al., 2002; Van Iddekinge et al., 2007). In our paper, we compare the relative effectiveness of two defensive IM tactics (justification versus excuses). We thus put forward the first hypothesis:

H1: For an entrepreneur who once experienced bankruptcy, the justification strategy 
(the person accepts responsibility for the failure but claims that it is not as bad as it appears) is better perceived by the recruiter during an employment interview than the excuses strategy (the person denies responsibility for the failure).

On the other hand, defensive tactics are not considered as rewarding in job interview situations (Chen \& Lin, 2014; Ellis et al., 2002). Many authors emphasize the virtues of failure in terms of learning, given that learning is not limited to a causal search. The lessons drawn from the failure then have to lead to subsequent changes in the behaviour of the individual (Cope, 2011; Ucbasaran et al., 2013). If entrepreneurs have really learned from their failure, why would they not be able to seize the opportunity of a recruiter's question about their failure in order to construct a favourable image (assertive IM tactic, by showing the experience and the knowledge acquired, their ability to overcome obstacles and their enhancement capacity), rather than attempting to repair their image (defensive IM tactic, through excuses or justification)? According to this view, failure is no longer seen by the applicant as a blight (Shepherd \& Haynie, 2011), but instead as an element that can be highlighted to produce a favourable impression. In short, there is a need for research that compares the perception of defensive and assertive IM tactics when it comes to explaining past failure during a job interview. We thus predict that:

H2: For an entrepreneur who once experienced bankruptcy, an assertive IM tactic (seeing failure as an opportunity to construct a positive image) is better perceived by the recruiter during an employment interview than defensive IM tactics (seeing failure as an event that tarnishes their mage, which has to be repaired) through excuses or justifications. 


\section{Methodology}

\section{Experimental Research}

We opted for an experimental method, a fairly classical choice in the field of IM tactics (Kristof \& Stevens, 1994). We relied on scenario research methodology. This methodology provides respondents with standardized stimuli, thus eliminating potential sources of interpretation error. Another advantage is to allow a very fine description of the context studied (Kacmar \& Carlson, 1999).

The experiment aimed to test the effect of the IM tactic used by the applicant on the attitude and reactions of the recruiter. We then manipulated the IM tactic used by the applicant and observed its effects on recruiter intentions. We first constructed scenarios simulating the job interview of a candidate for the position of sales director. We know that "when the extent of customer contact required for a job is relatively high (such as sales or customer-service jobs), interviewers may be more likely to pay attention to applicants' uses of IM tactics during job interviews" (Tsai et al., 2005, p. 111). In each script, the applicant was therefore invited to explain their previous experience. Our respondents were asked to act as if they were actually responsible for the recruitment of a sales manager.

We decided to present the scenarios in written form (not in video form) - a two-page document of around 800 words (the four questions asked by the recruiter in each scenario were exactly the same). This enabled us to focus on arguments developed by applicants and to rule out the effects of the nonverbal dimension of IM (such as gestures, smiles, physical appearance). Participants have been asked in past research to take the role of an interviewer in reading a dialogue between an applicant and an interviewer (Kacmar \& Carlson, 1999). In all the scenarios, the recruiter faced a 37-year-old man with over 12 years of experience, including eight years as an entrepreneur. This entrepreneurial experience had ended in bankruptcy and the applicant's narrative about the failure differs in each scenario. Each scenario differed in 
terms of the locus of control expressed by the applicant (external versus internal) and the IM tactic used (defensive/excuse; defensive/justification; assertive). Sentences were introduced into each scenario to highlight the IM tactics and the level of control expressed. In order to avoid a view that was overly caricatural of each case, around $20 \%$ of the sentences used in the three scenarios were identical.

In the first scenario, the applicant hides and denies responsibility for his failure (through external attribution), thereby attempting to protect his image (defensive/excuse strategy), and he tends to find the causes for his failure in his environment (such as economic crisis). In this scenario, the locus of control is low.

In the second scenario, the applicant does not hide and acknowledges some responsibility for his failure, but he attempts to protect his image by trying to convince the recruiters that the failure is not as bad as it looks and that he has acted appropriately (defensive/justification strategy). He tends to control his environment (high locus of control).

In the third scenario, the applicant does not hide and acknowledges some responsibility for his failure, and he attempts to actively construct a favourable image by showing that he has learned a lot and has made significant progress through failure (assertive strategy). As in the second scenario, the applicant shows that he controls his environment (high locus of control).

Thus, by building failure scenarios alone, we were able to create phrases on bankruptcy that we could easily compare with one another (see Table 1).

\section{[Insert Table 1]}

To ensure that the differences between the scenarios were correctly perceived by our respondents, our scenarios were tested by seven HR experts. We sent them a table with six excerpts from each scenario (120 words per extract on average). The experts were asked to link each extract with one of the three scenarios. Out of a total of 126 possibilities, only two 
mistakes were finally observed $(0.02 \%)$. Moreover, to ensure the realism of the situations described in the dialogue, the experts were asked to judge the scenarios on this criterion. No inconsistencies were identified.

\section{Preliminary Study}

A small preliminary study was conducted. The latter served to determine whether or not the different scenarios did elicit different reactions from our participants, and to pretest scales when such scales were developed or enriched by us. A sample of 43 students in an HR Management master's degree course was selected; they completed a survey-based questionnaire. We also implemented a focus group with 16 of these students to obtain deeper feedback on the items used in the questionnaire and regarding the sense given to words. Instead of focusing only on the decision to recruit or not the applicant in each scenario, the participants thought out loud (scenario by scenario). This verbal-protocol approach provided a richer understanding of the reasons that led them to take their decision (Shepherd \& Zacharakis, 1999, p. 203). We also adopted this analysis as our scales were inspired by North American research and we had to ensure that the translation took the French context attached to failure into account. This first preliminary study was useful to hone the measurement scales (for independent variables) and to marginally improve the three scenarios. The results of the pilot study are not included in the study but can be obtained on demand. After this stage, we finalized a six-screen questionnaire including 46 questions (http://enquete-0.launchrock.com/).

\section{Subjects in the Final Study}

A sample of $169 \mathrm{HR}$ professionals (for instance, HR director or head of recruitment) served as subjects in this experiment. The sample included 48 males (29\%) and 120 females (71\%), 52\% of whom were under 35 years old; $30 \%$ were between 35 and 45 years old, and $20 \%$ were over 45 . On average, our respondents have 7.7 years of experience in HR. 
The questionnaire was emailed to the HR professionals (across the entire French territory) through different networks. The respondents were randomly assigned one of the three scenarios and each respondent answered only one of the three scenarios $(\mathrm{n} 1=62, \mathrm{n} 2=58$, and $\mathrm{n} 3=49$ ). In order to create a natural framework, we did not reveal the scientific objectives of the survey to avoid influencing respondents. Like Tsai et al. (2005), we just specified that the study was concerned with the conduct of job interviews. The questionnaire was structured in three steps. In the beginning, we explained to the respondents the role of recruiters they were supposed to play and gave them information about the job and the applicant (through a created resume). At the end of this step, they had to give their first impression of the candidate (preinterview evaluation). In the second step, the subjects were randomly exposed to one of the three scenarios and were invited to read the corresponding dialogue between the applicant and a recruiter (three to five minutes in length). Finally, in the third step, they answered a series of questions including variables tested in the study and personal characteristics. On average, the respondents spent 14 minutes filling out the questionnaire, demonstrating good involvement in the task.

\section{Measures}

The questionnaire contained seven-point scales (from $1=$ totally disagree, to $7=$ totally agree) that measured independent (IM tactics), dependent (applicant's perception) and confounding variables (such as evaluation harshness, attitude toward failure). For most constructs, we used scales developed and tested by researchers. When scales were not available, we relied on the literature to develop our own items. As mentioned above, a pilot study was undertaken to test the reliability of measures in the French context and to improve the development of the scales (when scales were created). For each construct we ran factor analysis (factor extracted thanks to the rule of eigenvalues greater than 1). We followed an iterative process (Hair, Anderson, Babin, \& Black, 2010) that led to the removal of items with 
low communalities $(<0.5)$, low factor loading $(<0.5)$ or high cross-loading $(>0.4)$. The alpha coefficient was used to test the scale reliability. We also introduced questions about personal characteristics (age, recruitment experience, and gender).

Dependent variables. The impression left by the applicant on the recruiter was elicited by five variables: affective impression, intention to recruit, appropriateness of IM tactics, job/tactic-used fit, and the perceived sincerity of the applicant. We also appraised the preinterview evaluation (based only on the resume). The measurement scales and mono-items indices are detailed in Table 1 (Appendix A).

Confounding variables. The impression left by the applicant on the recruiter is liable to be different according to the recruiter's personal relationship with failure. We assessed the respondents' relationship to failure with questions on their familiarity with failure as a recruiter, their personal perception of failure, and the harshness of their evaluation of bankruptcy. Additionally, the recruiter's past experience is also likely to influence their perception of the applicant (Appendix A).

Independent variables. We identified three IM tactics thanks to the literature review: excuse strategy, justification strategy, and assertive tactic.

Assertive tactics have been researched extensively and several scales have been developed. We enriched the scale developed by Stevens and Kristof (1995) in order to introduce the assertive failure tactic dimension. The pilot study led us to retain a 10-item scale. This scale showed good reliability on the sample of HR professionals (Appendix A).

Concerning the measure of justification strategy, we designed a four-item scale based on previous studies (Tsai et al., 2005) and on the results of the pilot study. Unfortunately, the scale reliability was poor $(=0.53)$ and we thus preferred to keep one item to measure the justification tactic (in the same way as Tsai et al., 2005).

We defined excuse strategy as statements in which the speaker denies responsibility for the failure, tries to minimize his own role in this event, and highlights external causes that 
explain his failure (Stevens \& Kristof, 1995; Tedeschi \& Melburg, 1984). Based on the definitions and results of the pilot study, we developed a five-item scale to measure excuse strategy.

We measured the perceived locus of control of the applicant. We then adapted the scale of Russell (1982) to fit with the situation (perception of someone's locus of control). Five seven-point scales were used (two measures for the locus of causality, and three for controllability). The analysis factor led to the elimination of two items. The scale composed of three items presents good properties $(\propto=0,805)$ (Appendix A).

\section{Results}

The independent variable is the impression tactic used (excuse, justification, or assertiveness). The dependent variables included affective impression, intention to recruit, appropriateness of the tactics used, job/tactic-used fit, and perceived sincerity.

\section{Manipulation Check}

To ensure that impression management strategies were perceived differently and significantly across the three conditions, we compared the results of excuse tactic perception (ETP/Scenario1) to justification tactic perception (JTP/Scenario 2) and to assertive tactic perception (ATP/Scenario 3). We ran a Fisher test comparing the means of these three variables among the three scenarios. The ATP score is significantly different among the three scenarios $(\mathrm{F}=26.9, p<0,000)$ and significantly superior in the assertive scenario than in the justification $(\mathrm{ATP} 3-\mathrm{ATP} 2=0.813, p<0,001)$ or excuse scenario $(\mathrm{ATP} 3-\mathrm{ATP} 1=1.41, p<0,001)$. The justification tactic score is significantly different among the three scenarios $(F=11.107$, $p<0,000$ ), and this score is higher in the justification scenario than the excuse scenario (JTP2$\mathrm{JPT} 1=1.05, p<0,001)$ and the assertive scenario $(\mathrm{JTP} 2-\mathrm{JTP} 3=0.9, p<0,001)$. Finally, the 
perceived excuse tactic score differs among the three situations $(\mathrm{F}=94.57, p<0,001)$, and is higher in the excuse scenario than in the justification scenario $(\mathrm{ETP} 1-\mathrm{ETP} 2=2.16, p<0,001)$ or in the assertive scenario (ETP1-ETP3 $=2.47, p<0,001)$.

We also tested the difference in perceived locus of control between the three scenarios. The $t$-test demonstrated that perceived locus of control is different among the three scenarios ( $\mathrm{F}=14.6, p<0,001)$. As expected, in Scenario 1 (excuse strategy) the perceived locus of control (LC) is significantly smaller than in Scenario 2 (LC1-LC2 $=-0.825, p<0.001)$ and Scenario $3(\mathrm{LC} 1-\mathrm{LC} 3=-1.11, p<0,001)$.

We then concluded that the subject correctly perceived all three scenarios as being different in terms of the IM tactics used by the applicant.

\section{Preliminary Analysis}

Respondents were randomly assigned to one of the three scenarios. The descriptive analysis shows that groups do not differ in terms of personal characteristics (age chi squared $=0.966, p=0,617$, gender chi squared $=4.289, p=0.117$ ). Similarly, personal relationships with failure do not differ between scenarios (familiarity with failure $\mathrm{F}=0.745$, $\mathrm{p}=0.117$, personal perception of failure $\mathrm{F}=1.172, p=0.09$ ), and evaluation harshness $\mathrm{F}=1.17, \mathrm{p}=0.312$ ). The pre-evaluation of the candidate (based on the resume) is also similar between the three groups.

We performed several additional analyses in order to gain insights into the general perception of failure by recruiters (Table 2).

\section{[Insert Table 2]}

The results showed that the perception of failure (declarative position) by recruiters is around the mean score (4.53/7). Evaluation harshness also appears to be low (below the 
theoretical mean of the scale). However, a comparison of applicant evaluations before knowledge that his past experience was a failure and after discovering it highlights a devaluation of applicant perception. After reading the resume, the intention to invite the applicant to an interview is 5.6 on average, and at the end of the interview the intention to invite applicant to a second interview is 4.86 (the $t$-test shows a significant difference, $t=68.86$, $\mathrm{p}<0,001$ ). Additionally, the impression given by the applicant is better before the interview (5.49) than after (4.74) (the difference is significant, $t=63.5, p<0.001$ ). This confirms that failure seems to be a little more stigmatized by recruiters than they report.

We also compared failure perception based on respondents' characteristics. We may note that perception of failure does not differ among younger (under 35 years old) and older recruiters (over 35 years old), but that evaluation harshness is significantly higher among older recruiters (compared to younger ones).

\section{Role of IM Tactics on Recruiters' Appreciation}

We conducted an ANOVA to test the effects of impression management tactics on affective impression, appropriateness of the tactic used, intention to recruit, job/tactics fit, and perceived sincerity of the applicant. Note that all these variables are strongly correlated (Table 3) showing a global orientation of recruiter to applicant.

\section{[Insert Table 3]}

Concerning the different scenarios, ANOVA results indicated a significant difference between the composite means (Table 4).

[Insert Table 4] 
The post-hoc tests carried out (Table 5) highlight that the applicant in Scenario 3 is always preferred to the applicant in Scenario 1. The applicant in Scenario 3 is also preferred to the applicant in Scenario 2 except for affective appreciation and perceived sincerity, where the difference is not significant between applicants. Finally, the applicant in Scenario 2 is always preferred to the applicant in the first scenario except for the appropriateness of the tactic used. For this variable, no significant difference is found between applicants following an excuse tactic or a justification tactic. As expected, the assertive tactics produced a better outcome for employers than justification or excuse tactics. $H 1$ is supported. The justification tactics produced a better outcome on recruiters than the excuse tactics, so $H 2$ is also supported.

\section{[Insert Table 5]}

We ran a subgroup analysis to check if the recruiter's personal characteristics (age, gender, experience, personal relationship with failure) would influence recruiter appreciation. Tests show that no significant differences were found between men and women. A regression analysis run on each scenario highlights that individual perception of failure could explain the attitude of recruiters: a positive perception of failure tends to explain the positive affective impression of the applicant in Scenario 3 and the intention to recruit in Scenarios 2 and 1. We also found that, in Scenario 2 only, younger (and so less experimented) recruiters tend to be more easily seduced by IM tactics than older recruiters (the appropriateness of the tactics used, the perceived sincerity, and the intention to recruit are higher for young recruiters than for older recruiters). We observe this difference only for the justification tactic. 


\section{Discussion}

\section{Summary}

In this article, we compared the respective impact of IM tactics, two defensive and one assertive, in the discourse of PBE on recruiter evaluations in the context of job interviews. The literature has been silent on the reactions to be expected-in terms of assessment of the recruiter-when the conversation is steered to past failures. The specific case of entrepreneurs is particularly interesting because the latter have difficulty recreating a business after a bankruptcy (Simmons et al., 2014) and are more generally assumed to be victims of stigmatization (Shepherd \& Patzelt, 2015, Shepherd \& Haynie, 2011). We relied on a scenario research methodology (Kacmar \& Carlson, 1999), in which 169 French HR professionals participated. We establish that recruiters do not harshly stigmatize candidates who have suffered an entrepreneurial failure. Nevertheless, they pay close attention to the discourse on this subject during the job interview to see if the entrepreneurs have taken a step back and have developed as a result of this unfortunate experience. As such, it appears that the assertive IM tactic - in which failure is a central argument in self-valorization-is the one that makes the best impression among HR professionals.

\section{Contributions to Scholarship}

The literature usually postulates that PBEs have difficulty finding a job as an employee, without demonstrating it empirically. From this perspective, the PBE is systematically judged harshly and stigmatized by recruiters (Cope, 2011; Ucbasaran et al., 2013). This idea is challenged somewhat in our article. Indeed, we show that most recruiters are indulgent with a candidate who has undergone an entrepreneurial failure. They do not consider this setback a serious problem. So, a recruiter's initial impression of a PBE - in absolute terms, that is, independently of the job interview - is not necessarily negative, unlike that of a banker 
(Simmons et al., 2014). In other words, in the recruitment process, it seems that we do not find here the stereotyped beliefs usually associated with PBE (Link \& Phelan, 2001), whereby hiring this type of profile is risky for the company. In two of the three scenarios, the HR professionals have quite a positive impression of the applicant (even though the opinion is most favourable in the third scenario). Such a result may be surprising in a French cultural context (IPSOS, 2013), but may reflect a recent change in mentalities (as shown by many conferences or press articles on this topic over the last few years). On this point, it should be recalled here that evaluation harshness is weaker for the youngest HR professionals.

We emphasize here the simplistic approach adopted by the literature on the question of the representation of PBE by recruiters. The latter are more flexible and open on this issue than what is traditionally assumed. As such, they do not consider that a question about past failure (during the selection interview) is especially tricky. According to them, this is not intended to make the candidate feel uncomfortable. Today, it seems totally commonplace to talk about a past failure during a job interview. It is an element like any other, enabling recruiters to appraise the candidate. However, we can observe that the final assessment of the candidate (after the selection interview) is worse - in all scenarios - than the initial assessment (after reading the resume, in which the recruiter does not know that the break in activity was due to bankruptcy). A bankruptcy is thus described by recruiters as not being at all an issue, but in practice the score of the candidate nevertheless goes down slightly once the HR professionals become aware of the failure. Although it is clearly very limited in comparison to what the literature usually states, a small mark of stigmatization thus appears in our study.

However, we highlight here that the bankruptcy itself is less important for recruiters than the attitude of the entrepreneur regarding this failure. More precisely, when this issue is discussed during the job interview, the entrepreneur's sensegiving (Ucbasaran et al., 2013) is the decisive factor in their assessment. Do the candidates admit to their failure? Did they draw lessons from their failure? Did they change their behaviour after the failure? These are the 
questions the recruiter seeks to answer. As it happens, we confirm that the assertive IM tactic is assessed more positively by HR professionals than the defensive IM tactic (Gilmore \& Ferris, 1989). However, this is the first time that this result has been established in the specific context of a PBE. To the best of our knowledge, the effect of candidates' discourse regarding past failures during selection interviews on recruiters has not previously been studied (Silvester et al., 1992).

First, our findings contradict the conclusions of Kibler et al. (2017), according to whom distancing oneself from an entrepreneurial failure (through external attribution) is the most effective IM strategy with a public audience. Second, it should be remembered that individuals tend to be on the defensive when questioned about their failures (Shepherd \& Haynie, 2011; Tsai et al., 2010). The assertive IM tactic is therefore not the most spontaneous for them. The fact that the assertive IM tactic - that is, where the candidate uses their failure as a strength during the selection interview-is most widely appreciated by French recruiters confirms the idea of a change in societal representations about entrepreneurial failure.

Another contribution of our article is to avoid the Manichean approach adopted in the literature, which compares the effectiveness of assertive and defensive IM tactics (considering each of these two tactics as a homogeneous block). In particular, we show here that, in defensive IM tactics, justification is better than excuses in the eyes of recruiters. Moreover, in the justification scenario, they intend to hire the candidate, which is not the case in the excuses scenario. In other words, defensive behaviour is not necessarily perceived negatively by the recruiter if the entrepreneur steps back and has a questioning attitude. We thus show some nuances in defensive IM tactics. At all events, prior to our article, the exact effects of defensive IM tactics during job interviews were unknown (Ellis et al., 2002; Stevens \& Kristof, 1995). The article by Tsai et al. (2010) is obviously an exception in the literature, but our findings contradict the authors' conclusion that excuses and justifications were equally effective in the event of negative concerns about a candidate's competencies. 
In addition, our research also allows us to go beyond the traditional opposition in the literature between internal and external attribution of failure. Recruiters' preference for Scenarios 2 and 3 confirms that the self-complacency bias (Scenario 1) (Huff \& Schwenk, 1990) is a rejection factor for HR professionals. In other words, from their perspective, explanations of failures that are exclusively external are not reassuring (Jackson et al., 2009; Silvester et al., 2002). What is new in our study is that it shows that internal attribution may very well give rise to different attitudes on the part of the candidate and will not make the same final impression on recruiters. This underlines the interest of our narrative approach (Mantere, Aula, Schildt, \& Vaara, 2013), which allows us to analyze the causal attribution in a finer way. Indeed, the candidates' discourses are not binary. The individuals can thus fully recognize their responsibility, while doing their best to convince the recruiter that the failure was not as bad as it appears (that is, they try to protect their image despite failure). Conversely, the entrepreneurs can also admit to their mistakes, but focus their efforts on showing how they have grown professionally through this experience (that is, they attempt to actively construct a favourable image thanks to failure). Learning from failure - appreciated by recruiters - is therefore not simply a matter of sensemaking (Ucbasaran et al., 2013), but also of behaviour change.

Ultimately, a black-and-white analysis of job interviews (to simplify, defensive IM tactics are bad versus assertive IM tactics are good) must therefore be abandoned in favour of an approach in terms of continuum (from Scenario 1 to Scenario 3). In fact, the more easily the entrepreneurs recognize their failure, showing that they have learned from it and that they have improved professionally thanks to it, the better they "sell" themselves (Rosenfeld, 1997, p. 804). In this article, failure thus emerges as a potential lever-if (and only if) the candidate proves to the HR professional that this setback has been accepted, analyzed, and used to progress - and no longer as an impediment (Shepherd \& Haynie, 2011) in the recruitment process. In other words, trying to repair one's image after a failure is not the best IM tactic. This conclusion contradicts the results of Tsai et al. (2010), which "suggest that when an 
interviewer raises the failure experience of an applicant, the applicant will be better off if employing some kind of defensive IM tactic to protect his or her image" (p. 136). On the contrary, candidates can emphasize their post-failure rebound to demonstrate their skills (such as the ability to overcome obstacles or enhancement capacity). This is the IM tactic considered most appropriate by HR professionals. They do not have the feeling that the individual is overacting or manipulating when he chooses this IM tactic. Indeed, according to our respondents, this attitude is more credible and authentic than the excuse strategy and similar on this point to the justification strategy. Such a result may be due to the fact that a sales executive (as in our experimental study) is expected to have a learning capacity (Tsai et al., 2005).

As such, our article provides a better understanding of the concept of assertiveness in the context of post-failure job interviews. Traditionally, self-focused tactics are apprehended through highlighting of past accomplishments (Van Iddekinge et al., 2007). We show here that assertiveness can also be demonstrated by revealing a capacity to bounce back following a project in which the individual specifically did not accomplish what was first wanted. In other words, failure can be seen as a factor of valorization during a job interview if the assertive IM tactic is "skillfully executed" by the applicants (Rosenfeld, 1997, p. 803). We therefore enriched the measurement scales of this concept by introducing five new items in the literature. They relate to the individual's ability to overcome failure and to get better after failure, and are very strongly correlated with the items already available in the literature.

Finally, our study highlights a risk of "framing bias" (Tversky \& Kahneman, 1981) by PBEs. The HR professionals emphasize that having a selection interview with this kind of profile is rather uncommon. This may seem surprising since there are about 60,000 bankruptcies per year in France, and that most of the entrepreneurs concerned struggle to recreate (Simmons et al., 2014). This simply suggests that entrepreneurs do not try their luck enough in wage labour, because they expect to be judged harshly (Savitsky et al., 2001). This 
behaviour from PBEs may be analyzed as a form of self-selection resulting from an erroneous perception of failure by recruiters. Such a proposal is consistent with the finding of Savitsky et al. (2001), who affirm that the fear of post-failure stigmatization is commonly exaggerated. For entrepreneurs who nevertheless attempt to obtain salaried work, their poor representation of recruiters' reading grids - if it proves to be correct — is likely to lead them to adopt the wrong IM tactic during job interviews (defensive strategy instead of assertive strategy). In other words, there is a risk here of self-fulfilling prophecy: as a PBE, I feel that I will not be hired, because I believe that failure is judged harshly therefore I adopt a defensive IM tactic to protect my image therefore I don't construct a favourable impression therefore I am not recruited, as I feared. The candidate might then think that their non-recruitment confirms the general poor perception of failure by HR professionals, whereas it rather emphasizes the candidate's bad attitude during the selection interview. This would then correspond to a second level of external attribution.

\section{Applied Implications}

The use of an assertive IM tactic presupposes that candidates are able to learn from what has happened to them. This is not natural, given the multiple psychocognitive barriers to learning from failure (Ucbasaran et al., 2003). In our view, the tendency to mobilize external explanations following a failure does not always reflect a deliberate defensive IM tactic, but sometimes a difficulty putting things into perspective. This is why some PBEs should be accompanied in their sensemaking of failure (Jackson et al., 2009) before applying for wage labour.

\section{Limitations and Future Research Directions}

Our future research perspectives are the outcome of an inherent limitation of our work, namely that we took the profile of HR managers into account in a somewhat limited way (age, 
gender, and years of experience in recruitment). Thus, it would be interesting to investigate whether certain HR manager profiles are more open than others to applicants who have experienced entrepreneurial failure, depending on their own past experience in the field of entrepreneurship (or that of their close entourage), or their religious beliefs, for example.

\section{JEL classification: M12}

\section{References}

Bolino, M., Long, D., \& Turnley, W. (2016). Impression management in organizations: Critical questions, answers, and areas for future research. Annual Review of Organizational Psychology and Organizational Behavior, 3(1), 377-406.

Chapman, D., \& Rowe, P. (2001). The impact of videoconference technology, interview structure, and interviewer gender on interviewer evaluations in the employment interview: A field experiment. Journal of Occupational and Organizational Psychology, 74(3), 279-298.

Chen, C.-C., \& Lin, M.-M. (2014). The effect of applicant impression management tactics on hiring recommendations: Cognitive and affective processes. Applied Psychology: An International Review, 63(4), 698-724.

Chen, C.-C., Yang, I., \& Lin, W.-C. (2010). Applicant impression management in job interview: The moderating role of interviewer affectivity. Journal of Occupational and Organizational Psychology, 83(3), 739-757.

Cope, J. (2011). Entrepreneurial learning from failure: An interpretative phenomenological analysis. Journal of Business Venturing, 26(6), 604-623.

Ellis, A., West, B., Ryan, A.-M., \& DeShon, R. (2002). The use of impression management tactics in structured interviews: A function of question type? Journal of Applied 
Psychology, 87(6), 1200-1208.

Fletcher, C. (1992). Ethical issues in the selection interview. Journal of Business Ethics, 11(5), $361-367$.

Gilmore, D., \& Ferris, G. (1989). The effects of applicant impression management tactics on interviewer judgments. Journal of Management, 15(4), 557-564.

Hair, J., Anderson, R., Babin, B., \& Black, W. (2010). Multivariate data analysis: A global perspective (7th ed.). Englewood Cliffs, NJ: Prentice Hall.

Heider, F. (1958). The psychology of interpersonal relations. New York, NY: Wiley.

Howard, J., \& Ferris, G. (1996). The employment interview context: Social and situational influences on interview decisions. Journal of Applied Social Psychology, 26(2), 112136.

Huff, A., \& Schwenk, C. (1990). Bias and sensemaking in good times and bad. In A. Huff (Ed.), Mapping Strategic Thought (pp. 89-108). New York, NY: Wiley.

IPSOS (2013). How to spring back after a professional failure? www.ipsos.com/fr-fr/commentrebondir-apres-un-echec-professionnel.

Jackson, S., Hall, N., Rowe, P., \& Daniels, L. (2009). Getting the job: Attributional retraining and the employment interview. Journal of Applied Social Psychology, 39(4), 973-998.

Kacmar, K., \& Carlson, D. (1999). Effectiveness of impression management tactics across human resource situations. Journal of Applied Social Psychology, 29(6), 1293-1315.

Kacmar, K., Delery, J., \& Ferris, G. (1992). Differential effectiveness of applicant impression management tactics on employment interview decisions. Journal of Applied Social Psychology, 22(16), 1250-1272.

Kibler E., Mandl, C., Kautonen, T., \& Berger, E. (2017). Attributes of legitimate venture failure impressions. Journal of Business Venturing, 32(2), 145-161.

Kristof, A., \& Stevens, C. (1994). Applicant impression management tactics: Effects on interviewer evaluations and interview outcomes. Academy of Management Best Papers 
Proceedings (pp. 127-131).

Link, B., \& Phelan, J. (2001). Conceptualizing stigma. Annual Review of Sociology, 27(3), $363-385$.

Mantere, S., Aula, P., Schildt, H., \& Vaara, E. (2013). Narrative attributions of entrepreneurial failure. Journal of Business Venturing, 28(4), 459-473.

Rosenfeld, P. (1997). Impression management, fairness, and the employment interview. Journal of Business Ethics, 16(8), 801-808.

Roulin, N., Bangerter, A., \& Levashina, J. (2015). Honest and deceptive impression management in the employment interview: Can it be detected and how does it impact evaluations? Personnel Psychology, 68(2), 395-444.

Russell, D. (1982). The causal dimension scale: A measure of how individuals perceive causes. Journal of Personality and social Psychology, 42(6), 1137-1145.

Savitsky, K., Epley, N., \& Gilovich, T. (2001). Do others judge us as harshly as we think? Overestimating the impact of our failures, shortcomings, and mishaps. Journal of Personality and Social Psychology, 81(1), 44-56.

Schlenker, B. (1980). Impression management: The self-concept, social identity, and interpersonal relations. Monterey, CA: Brooks/Cole.

Schneider, D. (1981). Tactical-self-presentations: Toward a broader conception. In J. Tedeschi (Ed.), Impression management theory and social psychological research (pp. 23-40). New York, NY: Academic Press.

Shapiro, D. (1991). The effects of explanations on negative reactions to deceit. Administrative Science Quarterly, 36(4), 614-630.

Shepherd, D., \& Haynie, J. (2011). Venture failure, stigma, and impression management: A self-verification, self-determination view. Strategic Entrepreneurship Journal, 5(2), $178-197$.

Shepherd, D., \& Patzelt, H. (2015). Harsh evaluations of entrepreneurs who fail: The role of 
sexual orientation, use of environmentally friendly technologies, and observers' perspective taking. Journal of Management Studies, 52(2), 253-284.

Shepherd, D., \& Zacharakis, A. (1999). Conjoint analysis: A new methodological approach for researching the decision policies of venture capitalists. Venture Capital: An International Journal of Entrepreneurial Finance, 1(3), 197-217.

Silvester, J., Anderson-Gough, F., Anderson, N., \& Mohamed, A. (2002). Locus of control, attributions and impression management in the selection interview. Journal of Occupational and Organizational Psychology, 75(1), 59-76.

Simmons, S., Wiklund, J. \& Levie, J. (2014). Stigma and business failure: Implications for entrepreneurs' career choices. Small Business Economics, 42(3), 485-505.

Stevens, C., \& Kristof, A. (1995). Making the right impression: A field study of applicant impression management during job interviews. Journal of Applied Psychology, 80(5), $587-606$.

Struthers, W., Colwill, N., \& Perry, R. (1992). An attributional analysis of decision making in a personnel selection interview. Journal of Applied Social Psychology, 22(10), 801-818.

Tedeschi, J., \& Melburg, V. (1984). Impression management and influence in the organization. In S. Bacharach \& E. Lawler (Eds.), Research in the sociology of organizations (pp. 515523). Greenwich, CT: JAI Press.

Tsai, W.-C., Huang, T.-C., Wu, C.-Y., \& Lo, I.-H. (2010). Disentangling the effects of applicant defensive impression management tactics in job interviews. International Journal of Selection and Assessment, 18(2), 131-140.

Tsai, W.-C., Chen, C.-C., \& Chiu, S.-F. (2005). Exploring boundaries of the effects of applicant impression management tactics in job interviews. Journal of Management, 31(1), 108125.

Tucker, D., \& Rowe, P. (1979). Relationship between expectancy, causal attributions, and final hiring decisions in the employment interview. Journal of Applied Psychology, 64(1), 27- 
34.

Tversky, A., \& Kahneman, D. (1981). The framing of decisions and the psychology of choice. Science, 211(4481), 453-458.

Ucbasaran, D., Shepherd, D., Lockett, A., \& Lyon, S. (2013). Life after business failure: The process and consequences of business failure for entrepreneurs. Journal of Management, 39(1), 163-202.

Van Iddekinge, C., McFarland, L., \& Raymark, P. (2007). Antecedents of impression management use and effectiveness in a structured interview. Journal of Management, $33(5), 752-773$.

Zacharakis, A., Meyer, G., \& DeCas, J. (1999). Differing perceptions of new venture failure: A matched exploratory study of venture capitalists and entrepreneurs. Journal of Small Business Management, 37(3), 1-14. 


\section{Appendix A}

Table 1

Measurement Scale Used in the Study

\begin{tabular}{|c|c|c|c|}
\hline Construct & Items & Sources & $\begin{array}{c}\text { Cronbach } \\
\alpha\end{array}$ \\
\hline \multicolumn{4}{|c|}{ Dependent variables } \\
\hline \multirow{2}{*}{$\begin{array}{l}\text { Intention to recruit (before the } \\
\text { interview, based on resume) }\end{array}$} & $\begin{array}{l}\text { The written information provided by this applicant gave me a very } \\
\text { good impression. }\end{array}$ & \multirow[t]{2}{*}{$\begin{array}{l}\text { Chapman \& } \\
\text { Rowe, } 2001\end{array}$} & \multirow[t]{2}{*}{0.825} \\
\hline & I am likely to invite the applicant for an interview. & & \\
\hline \multirow{5}{*}{ Affective impression } & This applicant appears to be well qualified for the position. & \multirow{5}{*}{$\begin{array}{l}\text { Kacmar \& } \\
\text { Carlson, } 1999\end{array}$} & \multirow[t]{5}{*}{0.936} \\
\hline & This applicant has the ability to perform the job. & & \\
\hline & I like the individual. & & \\
\hline & I view this applicant favourably. & & \\
\hline & This applicant appears to be well qualified for the position. & & \\
\hline \multirow{2}{*}{$\begin{array}{l}\text { Intention to recruit (after the } \\
\text { interview) }\end{array}$} & I consider this applicant suitable for hiring in this organization. & \multirow{2}{*}{$\begin{array}{l}\text { Howard \& } \\
\text { Ferris } 1996\end{array}$} & \multirow[t]{2}{*}{0.936} \\
\hline & I am likely to invite the applicant to a second interview. & & \\
\hline $\begin{array}{l}\text { Appropriateness of the tactics } \\
\text { adopted }\end{array}$ & $\begin{array}{l}\text { The applicant's comments would not usually be found in the given } \\
\text { situation (reverse item). }\end{array}$ & $\begin{array}{l}\text { Kacmar \& } \\
\text { Carlson, } 1999\end{array}$ & \\
\hline Job/tactic fit & The applicant has the right attitude with regard to the job offered. & $\begin{array}{l}\text { Stevens \& } \\
\text { Kristof, } 1995\end{array}$ & \\
\hline Perceived sincerity & $\begin{array}{l}\text { The applicant seems sincere about the story of his failure and the } \\
\text { explanation for the causes of failure. }\end{array}$ & $\begin{array}{l}\text { Rosenfeld, } \\
1997\end{array}$ & \\
\hline \multicolumn{4}{|c|}{ Confounding variables } \\
\hline Failure familiarity & $\begin{array}{l}\text { Personally, do you exceptionally (1) vs. very frequently (7) meet } \\
\text { PBEs during job interviews? }\end{array}$ & $\begin{array}{l}\text { Item created } \\
\text { by researchers }\end{array}$ & \\
\hline Personal perception of failure & $\begin{array}{l}\text { Overall, do you consider the applicant's past experience a failure (1) } \\
\text { or as a success (7)? }\end{array}$ & Shapiro, 1991 & \\
\hline Failure evaluation harshness & $\begin{array}{l}\text { Do you think that this bankruptcy is (1) not a serious problem at all } \\
\text { vs. ( } 7 \text { ) a very serious problem? }\end{array}$ & $\begin{array}{l}\text { Shepherd and } \\
\text { Patzelt (2015) }\end{array}$ & \\
\hline Recruiter past experience & $\begin{array}{l}\text { Please indicate the number of years of recruitment experience you } \\
\text { have. }\end{array}$ & $\begin{array}{l}\text { Item created } \\
\text { by researchers }\end{array}$ & \\
\hline \multicolumn{4}{|c|}{ Independent variables } \\
\hline
\end{tabular}




\begin{tabular}{|c|c|c|c|c|}
\hline \multirow{10}{*}{$\begin{array}{l}\text { Perceived } \\
\text { assertive } \\
\text { tactics }\end{array}$} & \multirow{5}{*}{$\begin{array}{l}\text { Self- } \\
\text { promotion } \\
\text { dimension }\end{array}$} & Demonstrates knowledge and expertise. & \multirow{5}{*}{$\begin{array}{l}\text { Stevens \& } \\
\text { Kristof (1995) }\end{array}$} & \multirow[t]{5}{*}{0.86} \\
\hline & & Describes skills and abilities in a persuasive way. & & \\
\hline & & $\begin{array}{l}\text { Finds out what kind of person the organization is seeking and } \\
\text { explains how he fits in. }\end{array}$ & & \\
\hline & & Puts across his enthusiasm to work for this organization. & & \\
\hline & & Indicates his interest in the position and the company. & & \\
\hline & & Seems to have knowledge and expertise thanks to his past failure. & & 0.878 \\
\hline & & Shows how his failure improved his skills. & by researchers & \\
\hline & Failure & Shows his failure in a positive light. & & \\
\hline & $\begin{array}{l}\text { promotion } \\
\text { dimension }\end{array}$ & $\begin{array}{l}\text { Demonstrates that his past experience will be useful in the required } \\
\text { job. }\end{array}$ & & \\
\hline & & Seems to know how to avoid repeating past errors. & & \\
\hline Justificatio & ctics & $\begin{array}{l}\text { The applicant admitted to this mistake, but argued that his action } \\
\text { was acceptable in that situation. }\end{array}$ & $\begin{array}{l}\text { Tsai et al., } \\
2005\end{array}$ & \\
\hline & & Appears to ignore his past failure. & & 0.895 \\
\hline & & Speaking of his failure seems difficult . & by researchers & \\
\hline Excuse tac & & The applicant tends to attribute his failure to his environment. & & \\
\hline & & He attributes his failure to his colleagues. & & \\
\hline & & $\begin{array}{l}\text { The applicant does not seem to want to take responsibility for his } \\
\text { failure. }\end{array}$ & & \\
\hline Perceived & Is of control & $\begin{array}{l}\text { Causes evoked by the applicant seem to come from himself (his } \\
\text { decisions, his abilities, etc.). }\end{array}$ & Russell, 1982 & 0.805 \\
\hline & & Causes evoked by the applicant appear to be under his control. & & \\
\hline & & $\begin{array}{l}\text { Causes evoked by the applicant seem to be things he was } \\
\text { responsible for. }\end{array}$ & & \\
\hline
\end{tabular}


Table 1

Examples of Comparison of the Three Scenarios

\begin{tabular}{|c|c|c|}
\hline Scenario \#1 & Scenario \#2 & Scenario \#3 \\
\hline $\begin{array}{l}\text { "To be honest with you, I don't see } \\
\text { it as a failure because in the end I } \\
\text { still sold a lot of wooden chalets!" }\end{array}$ & $\begin{array}{l}\text { "Yes, we can call it a failure. } \\
\text { Having said that, I seem to have } \\
\text { read that only one in two } \\
\text { companies pass the five-year } \\
\text { mark." }\end{array}$ & $\begin{array}{l}\text { "Yes, we can call it a failure. But } \\
\text { personally, I see failure first and } \\
\text { foremost as a means to advance." }\end{array}$ \\
\hline $\begin{array}{l}\text { "Of course, I would have preferred } \\
\text { a different outcome, but it's not, } \\
\text { for all that, a failure in my eyes. } \\
\text { And it didn't change, in any case, } \\
\text { the person and the professional that } \\
\text { I am. I kept on track and I'm still } \\
\text { the same." }\end{array}$ & $\begin{array}{l}\text { "Of course, I would have preferred } \\
\text { a different outcome, but to me, it's } \\
\text { just one step in my career, like my } \\
\text { previous experiences. I don't think } \\
\text { it's something that will harm me } \\
\text { because the overall record of my } \\
12 \text { years in business remains } \\
\text { largely positive." }\end{array}$ & $\begin{array}{l}\text { "Of course, I would have preferred } \\
\text { a different outcome, but the } \\
\text { experience was very rewarding. It } \\
\text { was a key factor in my professional } \\
\text { development: there's clearly a } \\
\text { before and after this experience." }\end{array}$ \\
\hline
\end{tabular}


Table 2

Descriptive Analysis Concerning Personal Relationship with Failure

\begin{tabular}{|c|c|c|c|c|c|c|c|c|}
\hline & \multicolumn{2}{|c|}{$\begin{array}{c}\text { Global } \\
(\mathrm{n}=169)\end{array}$} & \multicolumn{2}{|c|}{$\begin{array}{c}\text { Scenario 1 } \\
(n=62) \\
\text { (excuse tactics) }\end{array}$} & \multicolumn{2}{|c|}{$\begin{array}{c}\text { Scenario } 2 \\
(\mathrm{n}=58) \\
\text { (justification tactics) }\end{array}$} & \multicolumn{2}{|c|}{$\begin{array}{c}\text { Scenario } 3 \\
(n=49) \\
\text { (assertive tactics) }\end{array}$} \\
\hline & M & SD & $\mathrm{M}$ & SD & $\mathrm{M}$ & SD & $\mathrm{M}$ & SD \\
\hline $\begin{array}{l}\text { Familiarity with failure } \\
\text { situation }\end{array}$ & 3.57 & 1.31 & 3.8 & 1.4 & 3.3 & 1.2 & 3.58 & 1.28 \\
\hline Failure perception & 4.53 & 1.12 & 4.29 & 1.06 & 4.6 & 1.19 & 4.73 & 1.07 \\
\hline Evaluation harshness & 3.33 & 1.25 & 3.43 & 1.24 & 3.12 & 1.15 & 3.45 & 1.38 \\
\hline
\end{tabular}


Table 3

Correlational Analysis

\begin{tabular}{|l|c|c|c|c|c|}
\hline & $\mathbf{1}$ & $\mathbf{2}$ & $\mathbf{3}$ & $\mathbf{4}$ & $\mathbf{5}$ \\
\hline 1. Affective Impression & 1 & & & & \\
\hline 2. Intention to Recruit & $0.804^{* * *}$ & 1 & & & \\
\hline $\begin{array}{l}\text { 3. Appropriateness of } \\
\text { Tactics Used }\end{array}$ & $0.554^{* * *}$ & $0.634^{* * *}$ & 1 & & \\
\hline 4. Job / Tactic Fit & $0.728^{* * *}$ & $0.728^{* * * * *}$ & $0.635^{* * *}$ & 1 & \\
\hline 5. Perceived Sincerity & $0.591^{* * *}$ & $0.567^{* * *}$ & $0.431^{* * *}$ & $0.639^{* * *}$ & 1 \\
\hline
\end{tabular}

Note. $* * *$ significant correlation $p<0,001 ; * *$ significant correlation $p<0,05$. 
Table 4

ANOVA Results

\begin{tabular}{|c|c|c|c|c|c|}
\hline & Sum of squares & Df & Mean Square & $\mathbf{F}$ & p value \\
\hline \multicolumn{6}{|c|}{ Affective Impression } \\
\hline Explained & 50.664 & 2 & 25.332 & 21.267 & 0.000 \\
\hline Residual & 189.390 & 159 & 1.191 & & \\
\hline Total & 240.055 & 161 & & & \\
\hline \multicolumn{6}{|c|}{ Intention to Recruit } \\
\hline Explained & 54.7 & 2 & 27.352 & 22.486 & 0.000 \\
\hline Residual & 200.7 & 165 & & & \\
\hline Total & 255.415 & 167 & & & \\
\hline \multicolumn{6}{|c|}{ Appropriateness of the Tactics Used } \\
\hline Explained & 55.509 & 2 & 27.755 & 11.807 & 0.000 \\
\hline Residual & 385.521 & 164 & 2.351 & & \\
\hline Total & 441.030 & 166 & & & \\
\hline \multicolumn{6}{|c|}{ Job/Tactic Fit } \\
\hline Explained & 105.35 & 2 & 52.676 & 32.545 & 0.000 \\
\hline Residual & 265.46 & 164 & 1.619 & & \\
\hline Total & 370.814 & 166 & & & \\
\hline \multicolumn{6}{|c|}{ Perceived Sincerity } \\
\hline Explained & 52.685 & 2 & 26.342 & 20.987 & 0.000 \\
\hline Residual & 207.101 & 165 & 1.25 & & \\
\hline Total & 370.814 & 167 & & & \\
\hline
\end{tabular}


Table 5

Self- Report Measures (7-Point Scale)

\begin{tabular}{|c|c|c|c|c|c|c|}
\hline & $\begin{array}{l}\text { Scen } \\
\text { (excu }\end{array}$ & $\begin{array}{l}1 \\
\text { actics) }\end{array}$ & $\begin{array}{l}\text { Scen } \\
\text { (just }\end{array}$ & & $\begin{array}{l}\text { Scen } \\
\text { (asse }\end{array}$ & tactics) \\
\hline & M & SD & M & SD & M & SD \\
\hline Affective impression (a)(b) & 4.04 & 1.33 & 4.98 & 1.03 & 5.36 & 0.75 \\
\hline Intention to recruit $(a)(b)(c)$ & 3.9 & 1.26 & 4.8 & 1.08 & 5.3 & 0.88 \\
\hline Appropriateness of the tactics used (a)(c) & 4.8 & 1.74 & 5.08 & 1.66 & 6.18 & 0.95 \\
\hline Job/tactics fit (a)(b)(c) & 3.5 & 1.36 & 4.55 & 1.43 & 5.45 & 0.86 \\
\hline Perceived sincerity (a)(b) & 4.31 & 1.39 & 5.4 & 1.05 & 5.53 & 0.73 \\
\hline
\end{tabular}

Note. (a) Means a significant difference between Scenario 1 and 3; (b) means a significant difference between Scenario 1 and 2; (c) means a significant difference between Scenario 2 and 3. 